\title{
Association of non-synonymous mutations in CD1A and CD1D genes with colorectal cancer in Saudi Arabia
}

\author{
S. Alomar ${ }^{1}$, J. Al-Tamimi ${ }^{1}$, T. Almanaa ${ }^{2}$, A. Al-jurayyan ${ }^{3}$, and \\ L. Mansour ${ }^{1,4}$ \\ ${ }^{1}$ Doping Research Chair, Zoology Department, College of Science, King \\ Saud University, Riyadh11451, Saudi Arabia \\ ${ }^{2}$ Department of Botany and Microbiology, College of Science, King Saud \\ University, Riyadh 11451, Saudi Arabia. \\ ${ }^{3}$ Immunology and HLA section, pathology and clinical laboratory Medicine, \\ King Fahad Medical city, Riyadh, Saudi Arabia \\ ${ }^{4}$ Higher Institute of Environmental Sciences and Technology, University of \\ Carthage, Hammam-Lif, Tunisia
}

Corresponding author: L. Mansour

E-mail: lamjed.mansour@gmail.com

Genet. Mol. Res. 19 (2): gmr18563

Received January 16, 2019

Accepted March 31, 2020

Published April 30, 2020

DOI http://dx.doi.org/10.4238/gmr18563

\begin{abstract}
Cluster of differentiation 1 (CD1) is antigenpresenting molecule involved in the presentation of lipid and glycolipid antigens to specific $\mathrm{T}$ cells and natural killer $\mathrm{T}$ cells. They exhibit a low rate of polymorphism compared to classical major histocompatibility complex presenting molecules. In this case control study, we examined a possible association of genetic polymorphism in CD1A and CD1D genes with colorectal cancer (CRC) in a Saudi population consisting of 120 patients with $\mathrm{CRC}$ and 118 matched controls. They were genotyped for the CD1A T/C 622 and CD1D A/T 354 polymorphisms using PCR-SSP. An apparent protective effect of the $\mathrm{C}$ allele, heterozygous $\mathrm{TC}$ and additive $\mathrm{TC}+\mathrm{CC}$ genotypes against $\mathrm{CRC}$ was observed. These associations were found only in individuals $>57$ years. No association was observed between the CD1D A/T 354 polymorphism and CRC.
\end{abstract}


Key words: Colorectal cancer; Genetic polymorphism; CD1 antigen presenting molecules; Saudi Arabia

\section{INTRODUCTION}

Colorectal cancer (CRC) is one of the leading causes of mortality and morbidity in the world. It's the third most prevalent cancer among males and fourth in females (Parkin et al., 2005). According to the Saudi Cancer Registry, CRC is the second most frequent malignancy after breast cancer, and the first most prevalent malignancy in men in Saudi Arabia Arabia (Saudi Cancer Registry (SCR), 2007; Alsanea et al., 2015). According to annual reports, this prevalence of CRC is increasing every year among the Saudi population as indicated by a three-fold rise in incidence in males from 3.2 to $11.2 \%$. A similar trend in females was observed for the same period with an increase from 2.7 to 8.8\% (Saudi Cancer Registry (SCR), 2007). Recently, The World Health Organization (WHO) has reported that the age-standardized death rate from CRC was $8.3 \%$ in Saudi Arabia (Al-Ahwal et al., 2013). Through established surveillance programs and subsequent early detection and removal of pre-cancerous colonic polyps, the incidence of CRC and its related deaths have decreased over the past 15 years in the United States, the highest CRC incidence country (Jackson-Thompson et al., 2006; Rim et al., 2009). In contrast, due to the lack of surveillance programs and insufficient molecular investigations, the increasing CRC incidence in Saudi Arabia suggests a potentially alarming situation. Genetics plays a role, to a greater or lesser extent, in most diseases. Actually, it's well admitted that genetic DNA polymorphism alongside the environment factors contribute to disease processes including cancer (Jackson et al., 2018). In this context, a large number of polymorphic sites have been reported to turn on the process of tumorigenesis confirming the strong heritable basis of cancer diseases (Law et al., 2019). Studying immune-related genetic markers, especially genes involved in the regulation of immune responses, is important to understand the role that the immune system could play in progression versus resorption of tumors.

Cluster of differentiation 1(CD1) molecules are major histocompatibility complex (MHC) class I-like glycoproteins expressed at the surface of antigen-presenting cells (APCs), cortical thymocytes and dendritic cells (DC) (Gumperz, 2006; Silk et al., 2008). They are involved in the presentation of lipid and glycolipid antigens to specific T cells and natural killer T cells (NKT) (Porcelli and Modlin, 1999; Cohen et al., 2009). The CD1 family of class I-like molecules, in contrast to MHC, is encoded outside the MHC genes, in chromosome1 (1q22-23). Molecule has a narrower and deeper antigen binding cleft than classical MHC-I (Martin et al., 1986). Increasing evidence suggests that they are part of a novel recognition system used by specialized populations of T cells (Martin et al., 1987; Brigl et al., 2006; Gumperz 2006). Also, CD1 molecules are different in that they can bind and present glycolipids, such as mycobacterial membrane components (Brigl et al., 2006). Even though CD1 molecules were discovered several decades ago, their functions and roles in antigen presentation and immune regulation are still being investigated (Gumperz, 2006). In human $\mathrm{g}$ five $\mathrm{CD} 1$ ones were identified, named $\mathrm{CD} 1 \mathrm{a},-\mathrm{b},-\mathrm{c},-\mathrm{d}$, and -e. The five isoforms of CD1 molecules are organized in to three groups in which CD1a, CD1b, and CD1c are members of group 1 that present both self and foreign glycolipids on dendritic cells to T cells. CD1d which belongs to group 2, presents both self and foreign glycolipids on antigen presenting cells to specialized natural killer T cells (NKT), and CD1e belongs to 
group 3 involved in antigen processing, is intracellular and never expressed on the cell surface (Gumperz, 2006). Functionally, the CD1 molecules have the tendency to attach foreign lipid antigens of infected APCs. In addition to the physiological functions described above, CD1 molecules have been reported in the pathogenesis of multiple sclerosis (MS), microbial infections, rheumatoid arthritis (RA) and malignancies (Cohenet al., 2009; Lawson 2012; Li et al., 2019). In ovarian carcinoma, the density of CDla positive Dendritic Cells (DC), reduces tumor recurrence and in tongue carcinoma the CD1a+ DC cells are associated with survival. In prostate cancers, the number of CD1a+ DC cells were lower compared to benign samples, however, in epithelial cells of metaplastic glands, CD1a was strongly expressed whereas in normal gastric and colonic mucosae it was negative (Coventry and Morton, 2003; Coventry and Heinzel, 2004; Cappello and Zummo, 2005). In the colorectal cancer and breast cancer CD1a+ DC cells were mainly found within the tumor, however, the CD83 mature dendritic cells were found around the tumor margin (Bell et al., 1999; Suzuki et al., 2002). Breast cancer patients with CD1a positive DC cells in sentinel lymph nodes are associated with higher tumor grades (Poindexter et al., 2004). Collectively, these findings suggest that CD1 molecules might have important functional roles in antitumor immune responses.

There is paucity of evidence that the characteristics found in general population will vary in Saudi Arabia based on the results of studies conducted in Australia, United States and the suburbs of Iran with similar findings on these molecules (Coventry and Heinzel 2004; Poindexteret al., 2004). Therefore, there is a need to study the various polymorphisms that may exist in the Saudi population and their association with susceptibility to cancer.

\section{MATERIAL AND METHODS}

\section{Participants and DNA isolation}

A total of 120 (68 males and 52 males, mean age of $57.1 \pm 12.7)$ Saudis diagnosed with CRC at King Khaled University Hospital (KKUH) at Riyadh, and 118 healthy individuals from the general Saudi population with no family history for CRC or any other chronic diseases were included in this study. Genomic DNA of the healthy control group and 48 CRC patients was extracted from the whole blood using the DNeasy Blood \& Tissue Kit (Qiagen, Valencia, CA, USA) according to the manufacturer's instructions. Genomic DNA for the rest of 72 of CRC patients was extracted from formalin-fixed, paraffin-embedded tissues (PFFPE) using a QIAamp DNA FFPE Tissue Kit (Qiagen, Valencia, CA, USA) according to the manufacturer's recommendations.

The study was performed with the approval of the ethical committee of King Saud University for this study and informed consent was obtained from all participants. For quality control, $5 \mu \mathrm{L}$ of the eluted genomic DNA was run in $1 \%$ agarose gel with a $1 \mathrm{~kb}$ ladder (Solis Biodyne, Estonia). DNA was quantitated using a NanoDrop 8000 (Thermo Scientific, USA)

\section{CD1 $A$ and CD1D genotyping}

The DNA fragment corresponding to exon 2 of CD1A and CD1D, genes were amplified with PCR using the primers already described (Han et al., 1999; Jones et al., 2001). For each gene, three primers were used, one common primer and two sequence 
specific primers for the both targeted alleles. A couple of primers amplifying a fragment of the $\beta$-globin was used as positive control for each PCR reaction. The PCR condition applied for this study were as follows: $1 \mathrm{~min}$ at $96^{\circ} \mathrm{C}$ followed by 5 cycles of $94^{\circ} \mathrm{C}$ for $20 \mathrm{~s}, 70^{\circ} \mathrm{C}$ for 40 $\mathrm{s}$ and $72^{\circ} \mathrm{C}$ for $40 \mathrm{~s}$, followed by 21 cycles of $94^{\circ} \mathrm{C}$ for $25 \mathrm{~s}, 65^{\circ} \mathrm{C}$ for $40 \mathrm{~s}$ and $72^{\circ} \mathrm{C}$ for $45 \mathrm{~s}$, followed by 4 cycles of $94^{\circ} \mathrm{C}$ for $20 \mathrm{~s}, 55^{\circ} \mathrm{C}$ for $30 \mathrm{~s}$ and $72^{\circ} \mathrm{C}$ for $120 \mathrm{~s}$. All PCR reactions were performed with the thermocycler T 100 (Biorad, USA). PCR products and 100 bp DNA Ladder (Solis BioDyne, Estonia) were electrophoresed in $2 \%$ agarose gel stained with ethidium bromide and visualized on an UV transilluminator using a gel documentation system (Biometra, Germany).

\section{Statistical Analysis}

The allele and genotype frequencies of CD1A and CD1D for patients and controls were determined by direct counting. Differences in the distribution of alleles and genotypes between patients and controls were estimated by a two-tailed Fisher's exact probability (p) test. A P value $<0.05$ was used as the criterion of statistical significance.

Odds ratio (OR) and $95 \%$ confidence interval $(95 \% \mathrm{CI})$ were calculated to assess the relative risk conferred by the alleles and genotypes. SigmaPlot software version 11 was used to perform all statistical.

\section{RESULTS}

This case control study was based on 120 colorectal cancer patients and 118 Saudi individuals. A demographic description of patients and controls is reported in Table 1. The mean age for patients and controls was about 56 years. No significant difference was observed in age gender distribution between patients and healthy controls $(\mathrm{P}=0.8$ and 0.6 respectively).

Table 1. Clinical and demographic profiles of Saudi colorectal cancer patients $(n=120)$ and controls $(n=$ 118). Percentages are shown in parentheses.

\begin{tabular}{|c|c|c|c|}
\hline Characteristi & & Cancer & Control \\
\hline \multirow{2}{*}{ Gender } & Male & $68(56.7)$ & $67(56.8)$ \\
\hline & Female & $52(43.3)$ & $51(43.2)$ \\
\hline \multirow[t]{2}{*}{ Age } & Mean \pm std & $57.1 \pm 12.73$ & $55.63 \pm 10.9$ \\
\hline & Colon & $65(54.2)$ & - \\
\hline \multirow{3}{*}{ Localization } & Sigmoid & $25(20.9)$ & - \\
\hline & rectosigmoid & $10(8.3)$ & - \\
\hline & Rectum & $20(16.6)$ & - \\
\hline \multirow{4}{*}{ Stage } & 0 & 2 & - \\
\hline & II & 95 & - \\
\hline & III & 12 & - \\
\hline & IV & 11 & - \\
\hline
\end{tabular}

For all individuals two polymorphisms CD1A $+622 \mathrm{~T} / \mathrm{C}$ and $\mathrm{CD} 1 \mathrm{D}+354 \mathrm{~A} / \mathrm{T}$, at exon 2 of CD1A and CD1D genes respectively were assessed. The distribution of alleles and genotypes among patients and controls and association analysis are reported in table 2. Genotype frequencies in controls were in Hardy-Weinberg equilibrium for the two polymorphisms (CD1A: $\chi^{2}=1.73, \mathrm{P}=0.18$; CD1E: $\chi^{2}=0.46, \mathrm{P}=0.49$ ). In normal Saudi population, the " $T$ " allele of CD1A was present in $73 \%$ of tested peoples, while the " $C$ " allele occurs $27 \%$. For the $C D 1 D$ gene, the " $A$ " allele was observed in all individuals while " $T$ " allele occurs in only $2 \%$ of 
examined population. Comparative analysis of the alleles and genotypes frequencies between patients and controls shows strong negative association between CRC and the occurrence CD1A $" C^{\prime \prime}$ allele $(\mathrm{OR}=0.59 ; \mathrm{CI}: 0.41-0.87$ and $\mathrm{P}=0.0045)$. The heterozygous " $T C$ " genotype show significant protective effect against $\mathrm{CRC}(\mathrm{OR}=0.29$; CI: 0.16-0.53; $\mathrm{P}=0.000039)$. Inversely, individuals sharing the homozygous "TT genotype have high risk to develop CRC (OR $=2.72$; $\mathrm{CI}=1.61-4.60 ; \mathrm{P}=0.00016$. The $C D 1 D+354 A / T$ polymorphism, did not show any significant association with CRC.

Table 2. Frequencies of CD1A and CD1D gene polymorphisms in Saudi colorectal cancer patients and controls.

\begin{tabular}{|c|c|c|c|c|c|}
\hline Polymorphism & $\begin{array}{c}\text { Patients } \\
\text { n (freq.) }\end{array}$ & $\begin{array}{l}\text { Control } \\
\text { n (freq.) }\end{array}$ & OR & CI & $P$ value \\
\hline CD1A T/C 622 & $(n=120)$ & $(\mathrm{n}=118)$ & & & \\
\hline $\mathrm{T}$ & (0.68) 164 & (0.56) 133 & Ref & & \\
\hline $\mathrm{C}$ & $(0.32) 76$ & (0.44) 103 & 0.59 & $0.41-0.87$ & 0.0045 \\
\hline $\mathrm{T} / \mathrm{T}$ & $71(0.59)$ & $41(0.35)$ & & & \\
\hline $\mathrm{C} / \mathrm{C}$ & $27(0.23)$ & $26(0.22)$ & 1.02 & $0.55-1.89$ & 1 \\
\hline $\mathrm{T} / \mathrm{C}$ & $22(0.18)$ & $51(0.43)$ & 0.29 & $0.16-0.53$ & 0.000039 \\
\hline $\mathrm{T} / \mathrm{C}+\mathrm{CC}$ & $49(0.2)$ & $77(0.33)$ & 0.52 & $0.34-0.80$ & 0.0026 \\
\hline \multicolumn{6}{|l|}{ CD1D A/T 354} \\
\hline A & $226(0.95)$ & $226(0.94)$ & & & \\
\hline $\mathrm{T}$ & $14(0.05)$ & $14(0.06)$ & 0.98 & $0.44-2.15$ & 1 \\
\hline AA & $106(0.88)$ & $104(0.88)$ & 1.01 & $0.46-2.24$ & 1 \\
\hline $\mathrm{TT}$ & 0 & 0 & - & & \\
\hline TA & $14(0.12)$ & $14(0.12)$ & 1 & & \\
\hline $\mathrm{TA}+\mathrm{TT}$ & $14(0.058)$ & $14(0.059)$ & 1 & & \\
\hline
\end{tabular}

In order to explore whether the $C D 1 A+622 T / C$ and $C D 1 D+354 A / T$ polymorphisms were associated with clinical parameters of the studied population, we stratified patients according to age; we distributed patients into two groups, those $\leq 56 \mathrm{y}$ and $>56$ patients and controls (Table 3 and 4). No association was found between CRC and any of alleles and genotypes for the group under 56 years. However there was an apparent strong protective effect for recessive $C$ allele and $T C$ genotype of the $C D 1 A+622$ polymorphic site. The $C D 1 D$ $+355 A / T$ polymorphism did not show any association.

Table 3. Genotype frequencies of Saudi CD1A and CD1D patients versus controls - age $\leq 56$.

\begin{tabular}{|c|c|c|c|c|c|}
\hline Polymorphism & $\begin{array}{l}\text { Patients } \\
\text { n (freq.) }\end{array}$ & $\begin{array}{l}\text { Control } \\
\text { n (freq.) }\end{array}$ & OR & CI & $P$ value \\
\hline CD1A T/C 622 & $(n=61)$ & $(n=55)$ & & & \\
\hline $\mathrm{T}$ & $79(0.65)$ & $66(0.60)$ & Ref & & \\
\hline $\mathrm{C}$ & $43(0.35)$ & $44(0.4)$ & 0.81 & $0.47-1.39$ & 0.5 \\
\hline $\mathrm{T} / \mathrm{T}$ & $33(0.54)$ & $21(0.38)$ & Ref & & \\
\hline $\mathrm{C} / \mathrm{C}$ & $15(0.24)$ & $10(0.18)$ & 1.46 & $0.59-3.60$ & 0.49 \\
\hline $\mathrm{T} / \mathrm{C}$ & $13(0.21)$ & $24(0.44)$ & 0.46 & $0.20-1.02$ & 0.07 \\
\hline $\mathrm{T} / \mathrm{C}+\mathrm{CC}$ & $28(0.23)$ & $34(0.25)$ & 0.52 & $0.25-1.09$ & 0.09 \\
\hline CD1D A/T 354 & $(\mathrm{n}=61)$ & $(\mathrm{n}=55)$ & & & \\
\hline A & $111(0.91)$ & $104(0.95)$ & Ref & & \\
\hline $\mathrm{T}$ & $11(0.09)$ & $6(0.05)$ & 1.71 & $0.61-4.8$ & 0.32 \\
\hline AA & $50(0.82)$ & $49(0.9)$ & & & \\
\hline TT & $0(0.0)$ & $0(0.0)$ & $\mathrm{Na}$ & & 1 \\
\hline TA & $11(0.18)$ & $6(0.1)$ & 1.79 & $0.61-5.23$ & 0.30 \\
\hline $\mathrm{TA}+\mathrm{TT}$ & $11(0.09)$ & $6(0.05)$ & 1.79 & $0.61-5.23$ & 0.30 \\
\hline
\end{tabular}

$\mathrm{n}$ : number of individuals; freq.: alles/genotype frequency; $\mathrm{O}=$ odds ratio; $\mathrm{CI}=$ confidence interval. 


\begin{tabular}{|c|c|c|c|c|c|}
\hline Polymorphism & $\begin{array}{l}\text { Patients } \\
\text { n (freq.) }\end{array}$ & $\begin{array}{l}\text { Control } \\
\mathrm{n} \text { (freq.) }\end{array}$ & OR & CI & $P$ value \\
\hline CD1A T/C 622 & $(n=59)$ & $(n=63)$ & & & \\
\hline $\mathrm{T}$ & $85(0.72)$ & $67(0.53)$ & & & \\
\hline $\mathrm{C}$ & $33(0.28)$ & $59(0.47)$ & 0.44 & $0.25-0.75$ & 0.0035 \\
\hline $\mathrm{T} / \mathrm{T}$ & $38(0.65)$ & $20(0.32)$ & & & \\
\hline $\mathrm{C} / \mathrm{C}$ & $12(0.20)$ & $16(0.25)$ & 0.75 & $0.32-1.75$ & 0.52 \\
\hline $\mathrm{T} / \mathrm{C}$ & $9(0.15)$ & $27(0.43)$ & 0.24 & $0.10-0.57$ & 0.0013 \\
\hline $\mathrm{T} / \mathrm{C}+\mathrm{CC}$ & $21(0.35)$ & $43(0.68)$ & 0.24 & $0.11-0.52$ & 0.0026 \\
\hline CD1D A/T 354 & $(\mathrm{n}=59)$ & $(\mathrm{n}=63)$ & & & \\
\hline A & $115(0.97)$ & $118(0.94)$ & & & \\
\hline $\mathrm{T}$ & $3(0.03)$ & $8(0.06)$ & 0.38 & $0.09-1.47$ & 0.21 \\
\hline AA & $56(0.95)$ & $55(0.87)$ & Ref & & \\
\hline TT & $0(0.0)$ & $0(0.0)$ & - & & \\
\hline TA & $3(0.05)$ & $8(0.13)$ & 0.36 & $0.09-1.46$ & 0.20 \\
\hline $\mathrm{TA}+\mathrm{TT}$ & $3(0.025)$ & $8(0.06)$ & 0.36 & $0.09-1.46$ & 0.20 \\
\hline
\end{tabular}

\section{DISCUSSION}

Colorectal cancer (CRC) is one of the most common cancers leading to death in Saudi Arabia and in the word (Al-Ahwalet al., 2013; Siegel et al., 2015). The dominant risk factor is still not yet revealed, while interaction between various factors mainly genetics, environmental and social could induce the appearance of the disease. Genetic alterations that may lead to colon cancer involve important genes including those that control immune response, causing dysregulation of the immune defense system. (Balkwill and Mantovani 2001; Gonzalez et al., 2018). One of important molecules in immune surveillance, are the Human Leukocyte Antigen (HLA) molecules, especially belonging to the class I system characterized by their extensive polymorphism and presented peptide antigens. Recently we have reported association between some genotypes of Killer Immunoglobulin like Receptors (KIR) and their HLA-C allotype ligands with colorectal cancer in the same cohort we studied here (Al Omar et al., 2015). Others genes we have also shown to be associated with colorectal cancer like $\beta$-Catenin and HLA-G molecule (Alomar et al., 2016; Abu-Hassan et al., 2019) Unlike the highly polymorphic classical HLA-class I molecules, CD1 are MHC-I like molecules, mediating lipid antigens presentation and exhibiting a very low genetic polymorphism including few nonsynonymous single nucleotide polymorphisms (SNPs) (Porcelli and Modlin 1999; Felio et al., 2009; Seshadri et al., 2013). Here we reported, the role of two nonsynonymous polymorphisms in CD1A and CD1D genes, $\mathrm{CD} 1 \mathrm{~A}+622 \mathrm{~T} / \mathrm{C}$ and CD1D $+355 \mathrm{~A} / \mathrm{T}$ respectively in the occurrence of colorectal cancer in Saudi population. The first polymorphic site belongs to the CDD1A gene is a transition mutation $(\mathrm{T} \rightarrow \mathrm{C}$ ) in the exon 2 conducing to a replacement of threonine with isoleucine at codon 13 (Han et al., 1999). The second polymorphism, located in exon 2 of the CD1D gene, is a trasversion $(\mathrm{A} \rightarrow \mathrm{T})$ allowing modification of serine to threonine at codon 46 . In this study we have detected strong relationship between the polymorphism CD1A $+622 \mathrm{~T} / \mathrm{C}$ and CRC. The $\mathrm{C}$ allele occurs more frequently in controls than in patients supporting a strong protective effect against the disease $(\mathrm{OR}=0.79$; IC : 0.41-0.87 and $\mathrm{P}=0.0045)$. The genotypes TC and TC $+\mathrm{CC}$ are also highly protective. Inversely the $\mathrm{CD} 1 \mathrm{D}$ studied polymorphism did not shows any association with CRC in the present population. Until 
now, only one previous study had explored association between these two polymorphisms and colorectal cancer in Iranian group (Golmoghaddam et al., 2011) . In this study, the relationship between these two polymorphisms with colorectal, breast and lung cancers, were evaluated in population from the south of Iran and no associations were detected with all these cancers. On previous studies, few associations were reported between some SNP polymorphic sites in CD1A or CD1D genes and infectious or autoimmune diseases like pulmonary tuberculosis (PMT) caused by Mycobacterium ssp, Guillain-Barré syndrome (GBS) and Multiple Sclerosis (MS). In Iranian populations, associations were reported between recessive genotypes of two polymorphic sites, outside the exon 2 and occurrence of PMT caused by Mycobacterium tuberculosis (Taheri et al., 2019). Similar result was reported for an intronic polymorphism of the CD1A and PMT in a Vietnamese population (Seshadri et al., 2014). On the other hand no associations were reported between CD1A and CD1D and PMT caused by Mycobacterium malmoense (Jones et al., 2001) .Significant associations were found between CD1A *01/02 and protection against GBS in Abruzzo region (Italy) population (Caporale et al., 2006) and in a Chinese population (Liu et al., 2016). However, no associations between GBS and CD1 A polymorphism were detected in German (Kuijf et al., 2008), Bangladeshi (Rahman et al., 2018) and Peruvian (JaramilloValverde et al., 2019) populations. Suggesting the potential effect of ethnicity in this discrepancy between populations. On the other hand, stratification of our study population according to the onset mean age of CRC, shows no effect of CD1A polymorphism in people less than 56 years. However, for > 57-year-old individuals, both CD1A T/C 622 and CD1D $+355 \mathrm{~A} / \mathrm{T}$ exhibited a similar pattern of association as in the overall population. This data could explain, in part the impact of age in the immune system and the highest predisposition to cancer disease for elder population.

\section{ACKNOWLEDGMENTS}

This study was financed by the Researchers Supporting Project number (RSP2019/35). King Saud University, Riyadh, Saudi Arabia.

\section{CONFLICTS OF INTEREST}

The authors declare no conflict of interest.

\section{REFERENCES}

Abu-Hassan MA, Al Omar S, Halawani H, Arafah M, et al. (2019). Relationship of HLA-G expression and its 14-bp insertion/deletion polymorphism with susceptibility to colorectal cancer. Genet. Mol. Res. 18: GMR18324.

Al-Ahwal MS, Shafik YH and Al-Ahwal HM (2013). First National Survival Data for Colorectal Cancer Among Saudis Between 1994 and 2004: What's Next? BMC Public Health. 13: 73.

Al Omar SY, Mansour L, Dar JA, Alwasel S, et al. (2015). The Relationship Between Killer Cell Immunoglobulin-Like Receptors and HLA-C Polymorphisms in Colorectal Cancer in a Saudi Population. Genet. Test Mol. Biomarkers. 19: 617-622.

Alomar SY, Mansour L, Abuderman A, Alkhuriji A, et al. (2016). beta-Catenin accumulation and S33F mutation of CTNNB1 gene in colorectal cancer in Saudi Arabia. Pol. J. Pathol. 67: 156-162.

Alsanea N, Abduljabbar AS, Alhomoud S, Ashari LH, et al. (2015). Colorectal cancer in Saudi Arabia: incidence, survival, demographics and implications for national policies. Ann. Saudi Med. 35: 196-202.

Balkwill F and Mantovani A (2001). Inflammation and cancer: back to Virchow? Llancet. 357: 539-545.

Bell D, Chomarat P, Broyles D, Netto G, et al. (1999). In breast carcinoma tissue, immature dendritic cells reside within the tumor, whereas mature dendritic cells are located in peritumoral areas. J. Exp. Med. 190: 1417-1426. 
Brigl M, van den Elzen P, Chen X, Meyers JH, et al. (2006). Conserved and heterogeneous lipid antigen specificities of CD1d-restricted NKT cell receptors. J. Immunol. 176: 3625-3634.

Cappello F and Zummo G (2005). CD1a immunopositivity could help to distinguish Barrett's metaplasia from heterotopic gastric mucosa. J. Gastroenterol. Hepatol. 20: 1308-1309.

Cohen NR, Garg S and Brenner MB (2009). Antigen Presentation by CD1 Lipids, T Cells, and NKT Cells in Microbial Immunity. Adv. Immunol. 102: 1-94.

Coventry B and Heinzel S (2004). CD1a in human cancers: a new role for an old molecule. Trends Immunol. 25: 242248.

Coventry BJ and Morton J (2003). CD1a-positive infiltrating-dendritic cell density and 5-year survival from human breast cancer. Br. J. Cancer. 89: 533-538.

Felio K, Nguyen H, Dascher CC, Choi HJ, et al. (2009). CD1-restricted adaptive immune responses to Mycobacteria in human group 1 CD1 transgenic mice. J. Exp. Med. 206: 2497-2509.

Golmoghaddam H, Pezeshki AM, Ghaderi A and Doroudchi M (2011). CD1a and CD1d genes polymorphisms in breast, colorectal and lung cancers. Pathol. Oncol. Res. 17: 669-675.

Gonzalez H, Hagerling C and Werb Z (2018). Roles of the immune system in cancer: from tumor initiation to metastatic progression. Genes Develop. 32: 1267-1284.

Gumperz JE (2006). The ins and outs of CD1 molecules: bringing lipids under immunological surveillance. Traffic. 7: 213.

Han M, Hannick LI, DiBrino M and Robinson MA (1999). Polymorphism of human CD1 genes. Tissue Antigens. 54: 122-127.

Jackson-Thompson J, Ahmed F, German RR, Lai SM, et al. (2006). Descriptive epidemiology of colorectal cancer in the United States, 1998-2001. Cancer. 107: 1103-1111.

Jackson M, Marks L, May GHW and Wilson JB (2018). The genetic basis of disease. Essays Biochem. 62: 643-723.

Jaramillo-Valverde L, Levano KS, Villanueva I, Hidalgo M, et al. (2019). Guillain-Barre syndrome outbreak in Peru: Association with polymorphisms in IL-17, ICAM1, and CD1. Mol. Genet. Genomic Med. 7: e00960.

Jones DC, Gelder CM, Ahmad T, Campbell IA, et al. (2001). CD1 genotyping of patients with Mycobacterium malmoense pulmonary disease. Tissue Antigens. 58: 19-23.

Kuijf ML, Geleijns K, Ennaji N, van Rijs W, et al. (2008). Susceptibility to Guillain-Barre syndrome is not associated with CD1A and CD1E gene polymorphisms. J. Neuroimmunol. 205: 110-112.

Law PJ, Timofeeva M, Fernandez-Rozadilla C, Broderick P, et al. (2019). Association analyses identify 31 new risk loci for colorectal cancer susceptibility. Nat. Commun. 10: 2154.

Lawson V (2012). Turned on by danger: activation of CD1d-restricted invariant natural killer T Cells. Immunol. 137: 2027.

Li C, Song B, Santos PM and Butterfield LH (2019). Hepatocellular cancer-derived alpha fetoprotein uptake reduces CD1 molecules on monocyte-derived dendritic cells. Cell Immunol. 335: 59-67.

Liu H, Xing Y, Guo Y, Liu P, et al. (2016). Polymorphisms in exon 2 of CD1 genes are associated with susceptibility to Guillain-Barre syndrome. J. Neurol. Sci. 369: 39-42.

Martin LH, Calabi F, Lefebvre FA, Bilsland CA, et al. (1987). Structure and expression of the human thymocyte antigens CD1a, CD1b, and CD1c. Proc. Natl. Acad. Sci. USA. 84: 9189-9193.

Martin LH, Calabi F and Milstein C (1986). Isolation of CD1 genes: a family of major histocompatibility complexrelated differentiation antigens. Proc. Natl. Acad. Sci. USA. 83: 9154-9158.

Parkin DM, Bray F, Ferlay J and Pisani P (2005). Global cancer statistics, 2002. CA Cancer J. Clin. 55: 74-108.

Poindexter NJ, Sahin A, Hunt KK and Grimm EA (2004). Analysis of dendritic cells in tumor-free and tumor-containing sentinel lymph nodes from patients with breast cancer. Breast Cancer Res. 6: R408-R415.

Porcelli SA and Modlin RL (1999). The CD1 system: antigen-presenting molecules for T cell recognition of lipids and glycolipids. Annu Rev. Immunol. 17: 297-329.

Rahman MI, Jahan I, Khalid MM, Jahan I, et al. (2018). CD1A and CD1E gene polymorphisms are not associated with susceptibility to Guillain-Barre syndrome in the Bangladeshi population. J. Neuroimmunol. 314: 8-12.

Rim SH, Seeff L, Ahmed F, King JB, et al. (2009). Colorectal cancer incidence in the United States, 1999-2004 : an updated analysis of data from the National Program of Cancer Registries and the Surveillance, Epidemiology, and End Results Program. Cancer. 115: 1967-1976.

Saudi Cancer Registry (SCR) (2007). Cancer Incidence and Survival Report Saudi Arabia. Ministry of Health, Kingdom of Saudi Arabia.

Seshadri C, Shenoy M, Wells RD, Hensley-McBain T, et al. (2013). Human CD1a deficiency is common and genetically regulated. J. Immunol. 191: 1586-1593.

Seshadri C, Thuong NT, Yen NT, Bang ND, et al. (2014). A polymorphism in human CD1A is associated with susceptibility to tuberculosis. Genes Immun. 15: 195-198.

Siegel RL, Sahar L, Robbins A and Jemal A (2015). Where Can Colorectal Cancer Screening Interventions Have the Most Impact? Cancer Epidemiol. Biomarkers Prev. 24: 1151-1156.

Silk JD, Salio M, Brown J, Jones EY, et al. (2008). Structural and functional aspects of lipid binding by CD1 molecules. Annu Rev. Cell. Dev. Biol. 24: 369-395.

Genetics and Molecular Research 19 (2): gmr18563

CFUNPEC-RP www.funpecrp.com.br 
Suzuki A, Masuda A, Nagata H, Kameoka S, et al. (2002). Mature dendritic cells make clusters with T cells in the invasive margin of colorectal carcinoma. J. Pathol. 196: 37-43.

Taheri M, Danesh H, Bizhani F, Bahari G, et al. (2019). Association between genetic variants in CD1A and CD1D genes and pulmonary tuberculosis in an Iranian population. Biomed. Rep. 10: 259-265. 